\title{
KINERJA BANGUNAN BERTINGKAT DI KAWASAN PESISIR DALAM MENUNJANG KEMARITIMAN DAN PARIWISATA DI BANYUWANGI
}

\author{
M. Shofi'ul Amin', Mirza Ghulam R. ${ }^{2}$, Dadang Dwi P. ${ }^{3}$, Erwin E. ${ }^{4}$ \\ 1,2,3,4 Jurusan Teknik Sipil, Politeknik Negeri Banyuwangi, Banyuwangi \\ e-mail: shofiul@poliwangi.ac.id, mirza@poliwangi.ac.id, dadang@poliwangi.ac.id, \\ triyayuk.zenfonego@gmail.com
}

\begin{abstract}
Banyuwangi is an area that belongs to zone 4 (SNI 03-1726-2002) and areas that are prone to earthquakes and are classified as moderate (SNI 03-1726-2012 and 2019). Other than, Banyuwangi also has the longest coastline on the island of Java, so buildings located in coastal areas have different air pressure that can cause very large winds to blow. So that in planning a building not only dead load and live load that needs to be planned but lateral loads also need to be planned. The survey results contained a tourism support building structure and are located very close to the coastal area of the Banyuwangi Dialoog Hotel. So the focus of this research is the construction of the structure. As for what is analyzed is the value of internal forces and deviations to the lateral loads of earthquake SNI 03-1726-2019 and wind loads based on PPIUG 1983 using the help of structural computer applications. The method used in earthquake load analysis is the spectrum response method. The results of the analysis of the value of the maximum force due to earthquake loads and wind loads are most influential on the column elements that cause inter-floor deviation. The deviation value is reviewed in the building service boundary performance, namely in the $x$ and $y$ directions respectively $10.89 \mathrm{~mm}$ and $15.75 \mathrm{~mm}$. When viewed from the service threshold value of $87.5 \mathrm{~mm}$, the structure is classified as safe from the influence of the lateral load of the planned earthquake and wind load. So that the building is feasible as a coastal building that is quite safe for commercial buildings and is able to become a tourist destination because it is so close to the sea.
\end{abstract}

Keywords: Coastal, lateral load, drift, tourism

\section{ABSTRAK}

Banyuwangi merupakan daerah yang termasuk wilayah zona 4 (SNI 03-1726-2002) dan daerah yang rawan terjadi gempa serta tergolong tingkat sedang (SNI 03-1726-2012 dan 2019). Selain itu, Banyuwangi juga memiliki garis pantai terpanjang di pulau Jawa, sehingga bangunan yang terletak di kawasan pesisir memiliki perbedaan tekanan udara yang bisa menyebabkan angin bertiup sangat besar. Sehingga dalam perencanaan suatu bangunan tidak hanya beban mati dan beban hidup saja yang perlu direncanakan melainkan beban lateral juga perlu direncanakan. Hasil survei terdapat struktur gedung penunjang pariwisata dan terletak sangat dekat sekali dengan kawasan pesisir yaitu Hotel Dialoog Banyuwangi. Maka fokus pada penelitian ini yaitu konstruksi pada struktur tersebut. Adapun yang dianalisis adalah nilai gaya dalam dan simpangan terhadap beban lateral gempa SNI 03-1726-2019 dan beban angin berdasarkan PPIUG 1983 dengan menggunakan bantuan aplikasi komputer struktur. Metode yang digunakan dalam analisis beban gempa adalah metode respon spektrum. Hasil analisa nilai gaya dalam maksimum akibat beban gempa dan beban angin yang paling berpengaruh yaitu pada elemen kolom yang mengakibatkan terjadinya simpangan antar lantai. Nilai simpangan tersebut ditinjau pada kinerja batas layan bangunan tersebut yaitu pada arah $x$ dan y masing-masing adalah 10,89 $\mathrm{mm}$ dan 15,75 $\mathrm{mm}$. Jika ditinjau dari nilai ambang batas layan yaitu 87,5 mm, maka struktur tersebut tergolong aman dari pengaruh beban lateral gempa rencana dan beban angin. Sehingga bangunan tersebut layak sebagai bangunan pesisir yang cukup aman untuk bangunan komersil serta mampu menjadi destinasi wisata karena letaknya yang sangat dekat dengan laut.

Kata kunci: Pesisir, beban lateral, simpangan, pariwisata 


\section{PENDAHULUAN}

Banyuwangi merupakan daerah yang memiliki panjang garis pantai sekitar $175,8 \mathrm{~km}$. Kondisi geografis wilayah pesisir Banyuwangi dengan keindahan pantainya memiliki nilai ekonomi dan mengalami kemajuan pesat di bidang pariwisata. Sehingga dengan kemajuan tersebut diiringi dengan meningkatnya pembangunan dan perbaikan infrastruktur serta fasilitas umum yang dilakukan pemerintah kota Banyuwangi maupun investor. Dalam melakukan pembangunan infrastruktur, perencanaan suatu struktur merupakan faktor yang sangat menentukan untuk menjamin kekuatan dan keamanan suatu bangunan agar struktur mampu memikul beban-beban yang ada [3].

Beban gempa dan beban angin juga perlu direncanakan sebagai beban lateral. Mengingat lokasi Banyuwangi merupakan daerah yang termasuk wilayah zona 4 [10] dan daerah yang rawan terjadi gempa serta tergolong tingkat sedang [11]. Selain itu, Banyuwangi juga memiliki garis pantai terpanjang sehingga bangunan yang terletak di kawasan pesisir memiliki perbedaan tekanan udara yang bisa menyebabkan angin bertiup sangat besar. Terpaan angin ini merupakan beban horizontal pada bangunan yang akan menimbulkan defleksi dan getaran bangunan, namun karena frekuensi dan periodenya lebih sering dan lama, maka akan dirasakan tidak nyaman oleh penghuni, Selain itu, semakin tinggi bangunan, defleksi lateral yang terjadi juga semakin besar pada lantai atas [1]. Sehingga menjadi hal yang sangat diperhitungkan untuk bangunan gedung bertingkat.

Dari penelitian terdahulu tentang analisis bangunan gedung bertingkat di lima wilayah di Indonesia terhadap beban gempa dan beban angin menunjukkan bahwa konstribusi beban angin tidak terlalu signifikan dibanding beban gempa karena kecepatan angin tidak terlalu besar [13] serta penelitian terhadap perbandingan respon struktur akibat beban gempa dan pengaruh angin pada gedung bertingkat tinggi juga menunjukkan bahwa tekanan angin rendah dikarenakan gedung terletak jauh dari pantai namun memiliki risiko kegempaan cukup tinggi [4]. Melihat hal tersebut, maka penelitian ini bertujuan melakukan analisa pada kinerja struktur pada konstruksi bangunan yang berada dikawasan pesisir terutama akibat beban gempa dan angin yang terjadi.

\section{METODE PENELITIAN}

Rencana kerja dalam penelitian yang akan dilakukan yaitu pertama dilakukan survei di sekitar kawasan pesisir pantai Banyuwangi, kemudian mengumpulkan literatur atau penelitian terdahulu sebagai sumber referensi dalam pengerjaan penyusunan laporan. Hasil survei terdapat struktur gedung penunjang pariwisata dan terletak sangat dekat sekali dengan kawasan pesisir yaitu Hotel Dialoog Banyuwangi. Maka pengumpulan data sekunder dan fokus pada penelitian ini yaitu konstruksi pada struktur tersebut. Setelah itu dilakukan pemodelan existing gedung secara 3D dan perhitungan pembebanan pada bangunan gedung. Perhitungan pembebanan meliput beban mati, beban hidup, beban gempa, dan beban angin. Perhitungan pembebanan selesai, dilanjutkan input data pembebanan dengan menggunakan program aplikasi komputer. Desain struktur ini dilakukan dengan analisis beban dinamik respon spektrum pada bangunan SRPMM (Struktur Rangka Pemikul Momen Menengah). Sistem ini pada dasarnya memiliki daktilitas sedang dan dapat digunakan di zona gempa 1 sampai 4[14] Setelah itu dilakukan analisa gaya dalam dan perhitungan simpangan yang terjadi. Hasil dan pembahasan akan didapatkan kesimpulan dan saran. Diagram alir 
penelitian ini ditunjukkan pada Gambar 1.

\section{HASIL dan PEMBAHASAN}

Hasil dan analisa ini didasarkan pada luaran dari perhitungan dari setiap peraturan yang ada dan diterapkan pada bangunan struktur gedung bertingkat yang sudah didapatkan dari hasil survei. Bangunan tersebut yaitu gedung hotel Dialoog yang lokasinya paling dekat dengan laut/bibir pantai. Bangunan ini akan dianalisa pengaruhnya terhadap beban lateral gempa dan angin, mengingat lokasi yang langsung menghadap ke laut.

\section{Data dan Pemodelan Struktur}

Adapun data-data spesifikasi perencanaan konstruksi bangunan Hotel Dialoog Banyuwangi yang digunakan pada penelitian ini adalah :

1. Nama Gedung : Hotel Dialoog Banyuwangi

2. Lokasi Gedung : Jl. Yos Sudarso, Kaliklatak, Klatak, Kec. Kalipuro, Kab. Banyuwangi, Jawa Timur

3. Fungsi Gedung : Hotel

4. Jenis Struktur: Beton Bertulang

5. Jumlah Lantai : 4 Lantai

6. Tinggi Bangunan $: 18,20 \mathrm{~m}$

7. Tinggi Lantai dasar: $4,2 \mathrm{~m}$

8. Tinggi lantai $1-4: 3,5 \mathrm{~m}$

9. Mutu Beton $\left(f_{c}{ }^{\prime}\right): 30 \mathrm{MPa}$

10. Mutu Baja $\left(f_{y}\right)$ : BJTS 40 dan BJTP 24

11. Tipe Kolom : Lantai dasar

Lantai 1- 4

$\mathrm{K} 1 \mathrm{~A} \& \mathrm{~K} 1=400 \times 700$

$\mathrm{K} 2 \mathrm{~A} \& \mathrm{~K} 2=250 \times 700$

$\mathrm{K} 1 \mathrm{~A} \& \mathrm{~K} 1=300 \times 700$

$\mathrm{K} 2 \mathrm{~A} \& \mathrm{~K} 2=250 \times 700$

12. Tipe Balok : B1 $250 \times 600$

B2 $250 \times 625$

B3 $200 \times 600$

B4 $250 \times 400$

B5 $200 \times 400$

Gambar 2 dan Gambar 3 adalah gambar denah, Gambar $\mathbf{4}$ adalah pemodelan struktur.

\section{Pembebanan Gravitasi}

Pada perhitungan beban gravitasi (vertikal) ini meliputi beban mati, beban mati tambahan dan beban hidup yang difokuskan pada struktur utama seperti yang terlihat pada pemodelan struktur yaitu pada elemen pelat, dinding geser, kolom dan balok. Hasil perhitungan beban tersebut akan disajikan pada Tabel 1 sampai Tabel 4.

\section{Beban Gempa}

Perhitungan beban gempa dilakukan untuk mengetahui kinerja bangunan jika terjadi gempa. Perhitungan beban gempa menggunakan acuan SNI 03-1726-2019 dengan metode respon spektrum. Sistem struktur yang digunakan harus sesuai dengan tingkat kerawanan daerah dengan struktur bangunan tersebut terhadap gempa [9]. Sehingga pada struktur bangunan ini menggunakan Struktur Rangka Pemkul Momen Menengah (SRPMM). Klasifikasi tanah yang digunakan untuk Kabupaten Banyuwangi yaitu tanah lunak, sehingga didapatkan nilai $S_{S}$ dan $S_{1}$ dari Puskim sebesar 0,8815 dan 0,3706. Sesuai dengan langkah perhitungan sesuai dengan SNI tersebut, didapatkan nilai $T_{0}=0,177$ detik, $T_{S}=0,886$ detik, dan $T_{L}=20$ detik, sehingga diperoleh beban gempa respons spektrum. Data respons spektrum kemudian diinputkan pada program komputer, sehingga didapatkan grafik respons spektrum yang dapat dilihat pada Gambar 5. 


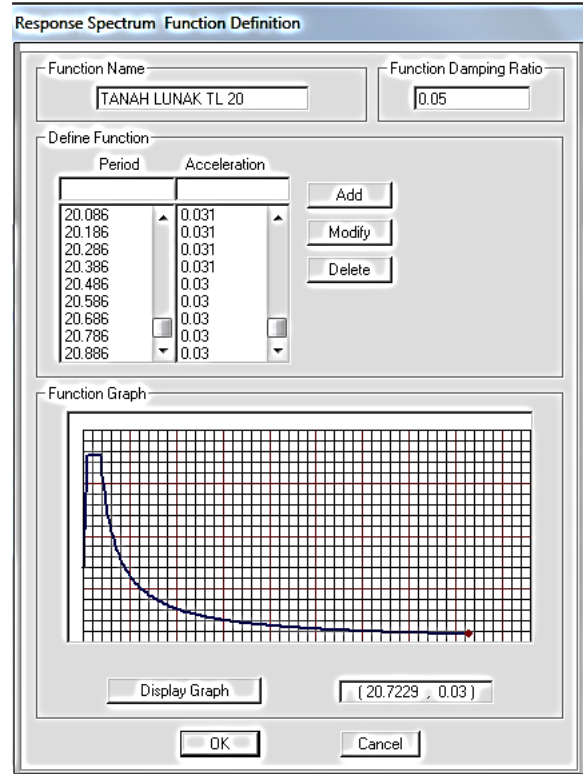

Gambar 5. Grafik Respons Spektrum Tanah Lunak Kabupaten Banyuwangi

\section{Beban Angin}

Menurut Peraturan Pembebanan Indonesia Untuk Gedung (PPIUG 1983), beban angin ditentukan dengan menganggap adanya tekanan positif dan tekanan negatif (isapan), yang bekerja tegak lurus pada bidang bidang yang ditinjau. Tekanan tiup di laut dan tepi laut sampai sejauh $5 \mathrm{~km}$ dari pantai harus diambil minimum $40 \mathrm{~kg} / \mathrm{m}^{2}$. Letak Hotel Dialoog Banyuwangi berada berbatasan langsung dengan pesisir pantai, sehingga beban angin diambil sebesar $40 \mathrm{~kg} / \mathrm{m}^{2}$. Hasil dari perhitungan beban angin yang bekerja pada konstruksi gedung tersebut disajikan pada Tabel 5 dan Tabel 6.

\section{Analisa Struktur}

Pada tahap analisa struktur ini akan dilakukan dengan bantuan aplikasi komputer struktur dalam mencari gayagaya dalam yang terjadi pada konstruksi bangunan tersebut. Sedangkan perhitungan simpangan yang terjadi dihitung berdasarkan ketentuan pada SNI 03-1726-2019 yang sekaligus dijadikan sebagai acuan dalam pertimbangan keamanan struktur ditinjau dari beban lateral yang terjadi. Hal tersebut sangat dibutuhkan mengingat rata-rata periwisata yang dikembangkan di Banyuwangi yaitu terletak pada wahana pantai. Sehingga tidak sedikit bangunan pelengkap wisata seperti hotel yang terletak di kawasan pesisir. Selain itu pertimbangan tersebut juga akan memberikan gambaran dari bangunan-bangunan yang akan didirikan sebagai pertimbangan beban lateral yang terjadi. Sekaligus akan memperkuat daerah maritim wilayah terluar dari pulau Jawa.

Hasil gaya dalam setiap elemen struktur akan disajikan dalam Gambar 6 sampai dengan Gambar 8.

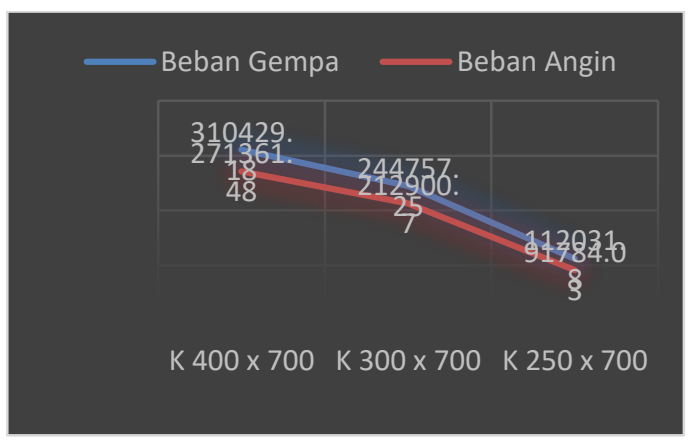

(a)

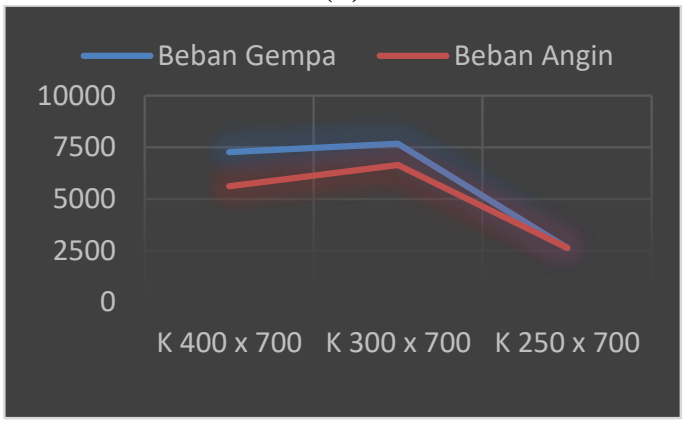

(b)

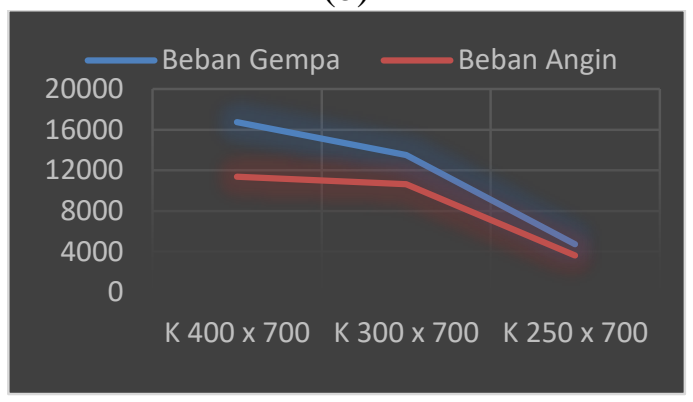

(c)

Gambar 6. Grafik Gaya Aksial (a), Geser (b) dan Momen (c) Maksimum pada Kolom Struktur Akibat Beban Lateral Gempa dan Angin 


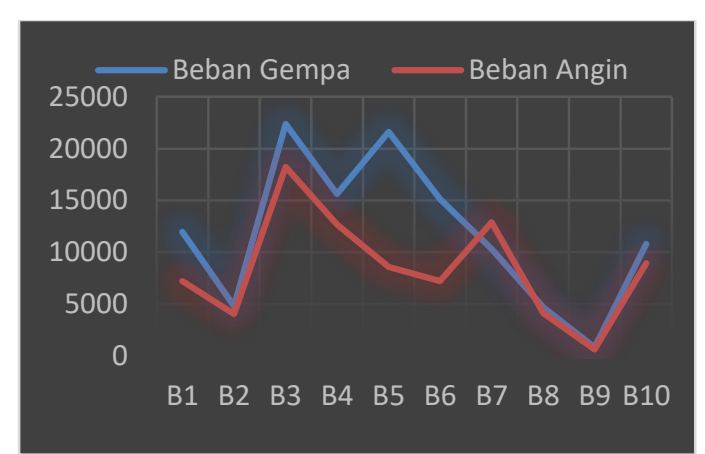

(a)

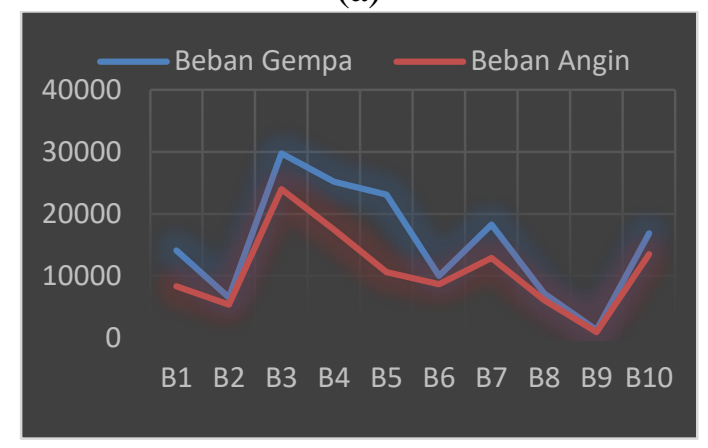

(b)

Gambar 7. Grafik Gaya Geser (a) dan Momen (b) Maksimum pada Balok Akibat Beban Lateral Gempa dan Angin

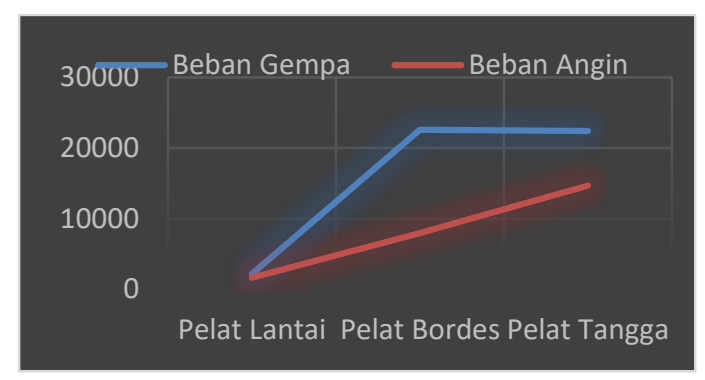

Gambar 8. Grafik Momen Maksimum pada Pelat Akibat Beban Lateral Gempa dan Angin

Gambar 6 sampai Gambar 7 terlihat bahwa nilai gaya dalam akibat beban gempa bernilai lebih besar dibandingkan dengan beban angin. Hal tersebut menunjukkan bahwa beban gempa lebih dominan dibandingkan dengan beban angin walaupun bangunan terletak dikawasan pesisir. Maka perilaku struktur juga perlu dipertimbangkan simpangan yang terjadi akibat beban gempa, agar dapatnya diketahui kinerja simpangan antar lantai yang terjadi (kinerja batas layan).

\section{Analisa Nilai Simpangan}

Kinerja batas layan struktur gedung ditentukan oleh simpangan antar tingkat akibat pengaruh beban gempa rencana. Hal ini dilakukan untuk mencegah terjadinya pelelehan baja dan peretakan pada bangunan beton yang berlebihan, selain untuk mencegah kerusakan non struktural maupun ketidaknyamanan penghuni. Hasil analisa nilai simpangan yang terjadi akibat beban lateral (gempa dan angin) yang dapat dilihat pada Tabel 7.

Nilai simpangan yang terjadi semuanya menunjukkan bahwa simpangan yang terjadi masih lebih kecil dari yang dipersyaratkan oleh SNI 03-1726-2019. Struktur akan dikatakan aman apabila simpangan antar lantai desain $(\Delta)$ tidak melebihi simpangan antar lantai ijin $\left(\Delta_{a}\right)$. Adapun selisih nilai yang ditunjukkan memiliki deviasi yang cukup jauh. Hal tersebut juga diperkuat dengan penelitian Oktoriyanto dkk tahun 2015 yaitu konstribusi akibat beban angin pada struktur gedung tidak terlalu signifikan dibanding beban gempa karena kecepatan angin tidak terlalu besar walupun bangunan termasuk high rise building [2]. Serta penelitian Rizki yang menunjukkan bahwa pembebanan gempa statis menyebabkan deformasi yang lebih besar pada struktur dibandingkan pembebanan angin [7].

\section{KESIMPULAN}

Berdasarkan hasil penelitian dan analisa pada konstruksi hotel bertingkat yang terletak dikawasan pesisir Kabupaten Banyuwangi ditinjau dari beban lateral, maka dapat disimpulkan yaitu :

a. Gaya dalam yang ditimbulkan pada struktur utama bangunan lebih dipengaruhi akibat beban gempa dibandingkan beban angin yang terjadi.

b. Konstruksi gedung penunjang pariwisata (studi kasus Hotel Dialoog) Banyuwangi memiliki 
kategori aman jika ditinjau dari simpangan antar lantai yang terjadi.

c. Simpangan yang terjadi masih memenuhi batas simpangan yang disyaratkan oleh standar pembebanan gempa pada SNI 031726-2019.

\section{SARAN}

Saran yang bisa diberikan dari hasil penelitian ini adalah bisa dilanjutkan pada tahap evaluasi sampai pada pengaruh dari topografi dikawasan sekitar bangunan dan diperhitungkan juga terkait terjadinya beban besar seperti gempa yang disertai dengan tsunami.

\section{DAFTAR PUSTAKA}

[1] A. Hasan dan I.F Astira, "Analisis perbandingan Simpangan Lateral Bangunan Tinggi Dengan Variasi bentuk dan Posisi Dinding Geser Studi Kasus : Proyek Apartemen The Royale Springhill Residences," Jurnal Teknik Sipil dan Lingkungan. Vol 1 No 1. pp-47-56, 2013.

[2] A. Oktoryanto dan M. Teguh, "Perbandingan Respons Struktur Akibat Beban Gempa dan Beban Angin Statik Gedung". Jurnal Teknik Sipil dan Perencanaan, 922934, 2015.

[3] A. Simatupang, Bayzoni, dan A. Kusnadi, "Analisis dan Desain Elemen Struktur Beton Bertulang Pada Gedung Yang Memiliki Kolom Miring Dengan Sistem Rangka Pemikul Momen Biasa (SRPMB)". Jurnal Rekayasa Sipil dan Desain Vol.7, No. 2, 2019.

[4] Baehaqi, Z. Darwis, H.B.B Kuncoro, Prastyani, Perbandingan Respon Struktur Akibat Beban Gempadan Pengaruh Angin Pada Gedung Bertingkat Tinggi (Studi kasus : Gedung Menara Rektorat Kampus UNTIRTA Sidangsari). Jurnal Fondasi, Vol. 8, No. 1, 2019.
[5] Desain Spektra Indonesia, rsapuskim2019.litbang.pu.co.id.

[6] K. N. Firdausyah dan W. Atikah, "Peran Pemerintah Banyuwangi terhadap Bangunan Pinggir Pantai," Jurnal Lentera Hukum, Vol. 5, No. $1,2018$.

[7] M. Rizki, "Analisis Pengaruh Beban Gempa Statik Ekivalen dan angin pada struktur gedung dengan variasi rasio kelangsingan bangunan," Universitas Andalas Padang, Padang, 2011.

[8] Peraturan Pembebanan Indonesia Untuk Gedung 1983, Peraturan Pembebanan Indonesia Untuk Gedung 1983, Bandung: Yayasan Lembaga Penyelidikan Masalah Bangunan, 1983.

[9] R. Rendra, A. Kurniawandy, dan Z. Djauhari, Kinerja Struktur Akibat Beban Gempadengan Metode Respon Spektrum dan Time History (Studi Kasus : Hotel SKA Pekanbaru)," JOM FTEKNIK, Vol. 2, No. 2, 2015.

[10] SNI 03-1726-2002, Standar Perencanaan Ketahanan Gempa Untuk Struktur Bangunan Gedung dan Non Gedung, Jakarta: Badan Standardisasi Nasional, 2002.

[11] SNI 03-1726-2012, Tata Cara Perencanaan Ketahanan Gempa Untuk Struktur Bangunan Gedung dan Non Gedung. Bandung: Badan Standardisasi Nasional, 2012.

[12] SNI 03-1726-2019, Tata Cara Perencanaan Ketahanan Gempa Untuk Bangunan Gedung dan Non Gedung, Jakarta: Badan Standardisasi Nasional, 2019.

[13] Soelarso, Baehaki, A. Mursyidan,"Analisis Struktur Gedung Bertingkat Di Lima Wilayah Di Indonesia Terhadap Beban Gempa dan Beban Angin Menurut SNI 1726-2012 dan SNI 1727-2013", Jurnal Fondasi, Vol. 6, No. 1, 89-100, 2017. 
[14] Y. Tajunnisa, M. Chadaffi, dan V. Ramadhaniawan, "Perbandingan evaluasi kinerja bangunan gedung tahan gempa antara metode SRPMM dan SRPMK," Jurnal Aplikasi, Vol. 12, No. 1, 2014.

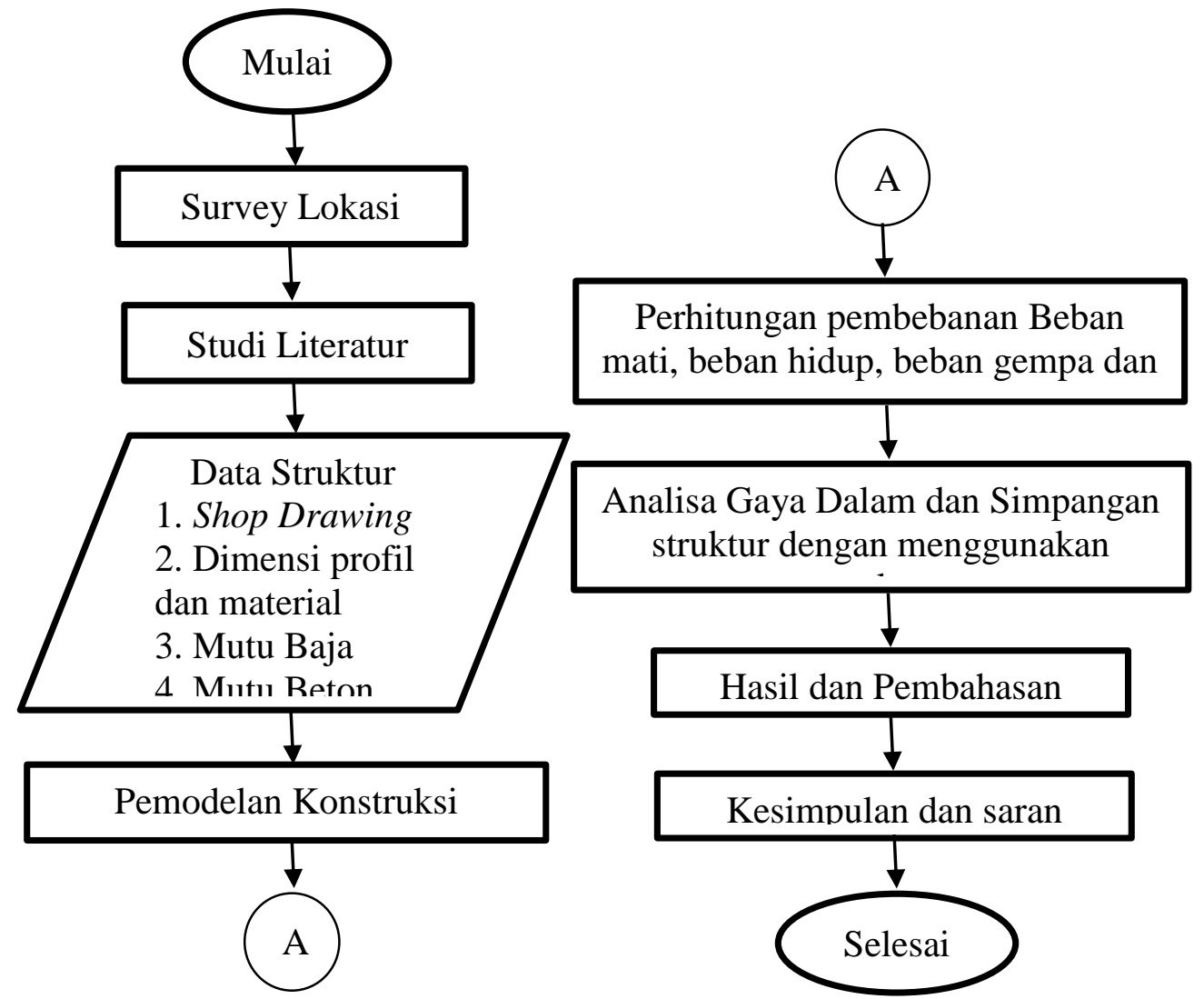

Gambar 1. Diagram Alir Penelitian

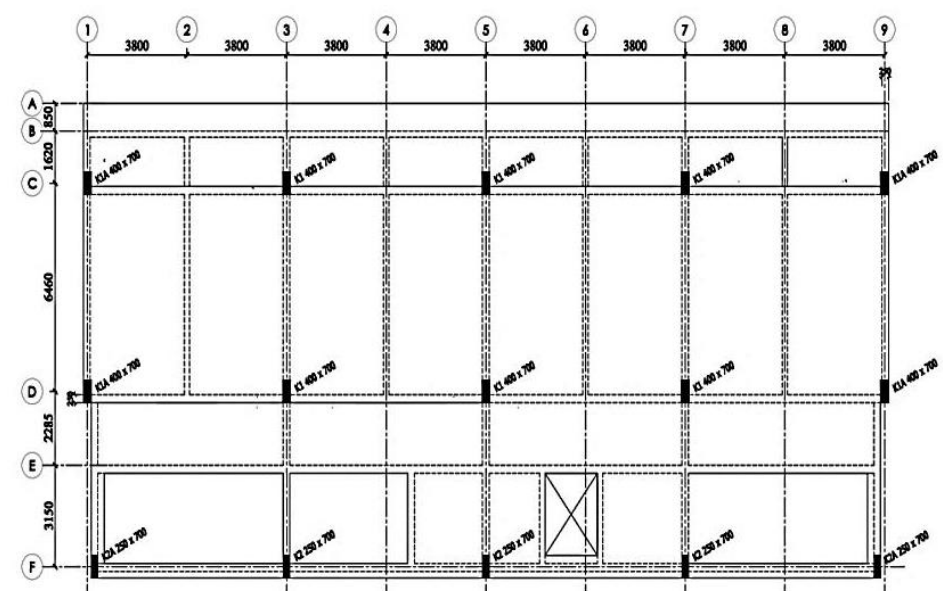

Gambar 2. Denah Hotel Dialoog Banyuwangi Lantai ground 


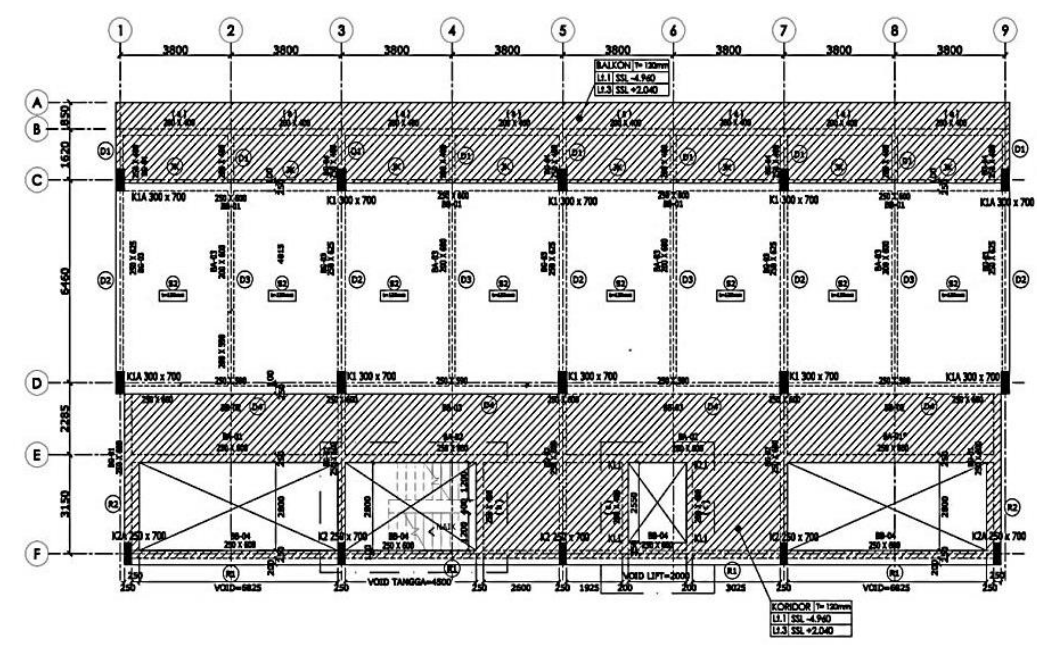

Gambar 3. Denah Hotel Dialoog Banyuwangi Lantai typikal (1-4)

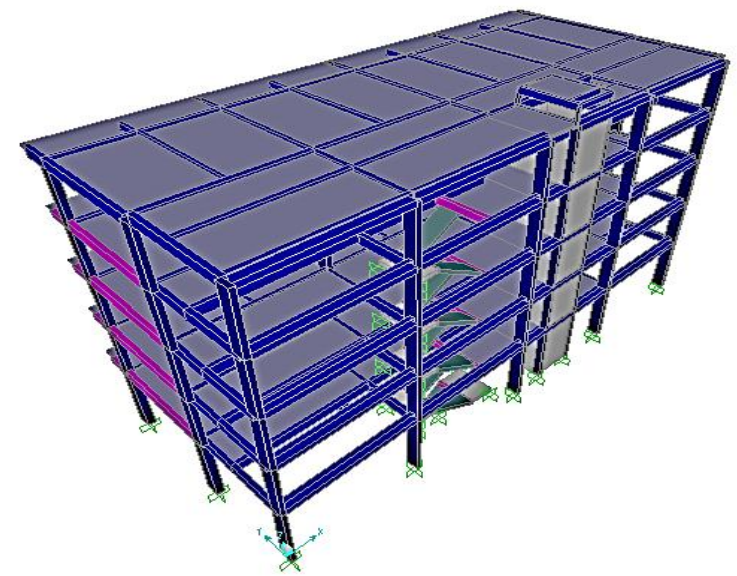

Gambar 4. Pemodelan Struktur

Tabel 1. Beban Gravitasi pada Elemen Pelat Lantai, Atap, Tangga dan Bordes

\begin{tabular}{|c|c|c|c|c|c|}
\hline \multirow{3}{*}{ Lokasi } & \multirow{3}{*}{ Ukuran Pelat } & \multirow{3}{*}{ Jumlah } & \multicolumn{3}{|c|}{ Jenis Beban } \\
\hline & & & \multicolumn{2}{|c|}{ Beban Mati $\left(\mathrm{kg} / \mathrm{m}^{2}\right)$} & \multirow{2}{*}{$\begin{array}{l}\text { Beban Hidup } \\
\left(\mathrm{kg} / \mathrm{m}^{2}\right)\end{array}$} \\
\hline & & & Beban Mati & $\begin{array}{r}\text { Beban Mati } \\
\text { Tambahan }\end{array}$ & \\
\hline \multirow{8}{*}{ Pelat Lantai } & $2,47 \times 7,6$ & 16 & 86501,38 & 26256,77 & 75088 \\
\hline & $3,8 \times 6,46$ & 32 & 226234,37 & 68671,56 & 196384 \\
\hline & $2,285 \times 7,45$ & 8 & 39221,57 & 11905,38 & 34046,5 \\
\hline & $2,285 \times 7.6$ & 8 & 40011,26 & 12145,09 & 34732 \\
\hline & $3,15 \times 3,15$ & 4 & 11430,72 & 3469,69 & 9922,5 \\
\hline & $2,050 \times 3,15$ & 4 & 7439,04 & 2258,06 & 6457,5 \\
\hline & $2,850 \times 3,15$ & 4 & 10342,08 & 3139,25 & 8977,5 \\
\hline & \multicolumn{2}{|l|}{ Total } & 421180,42 & 127845,81 & 365608 \\
\hline \multirow{10}{*}{$\begin{array}{c}\text { Pelat Lantai } \\
\text { Atap }\end{array}$} & $2,47 \times 7,6$ & 4 & 21625,34 & 5137,52 & 7508,8 \\
\hline & $3,8 \times 6,46$ & 8 & 56558,59 & 13436,59 & 19638,4 \\
\hline & $2,285 \times 7,45$ & 2 & 9805,39 & 2329,46 & 3404,65 \\
\hline & $2,285 \times 7,6$ & 2 & 10002,82 & 2376,36 & 3473,2 \\
\hline & $3,15 \times 3,15$ & 1 & 2857,68 & 678,90 & 992,25 \\
\hline & $2,050 \times 3,15$ & 1 & 1859,76 & 441,82 & 645,75 \\
\hline & $2,4 \times 3,15$ & 1 & 2177,28 & 517,25 & 756 \\
\hline & $3,15 \times 7,45$ & 2 & 13517,28 & 3211,29 & 4693,5 \\
\hline & $3,15 \times 7,6$ & 1 & 6894,72 & 1637,97 & 2394 \\
\hline & \multicolumn{2}{|c|}{ Total } & $\mathbf{1 2 5 2 9 8 , 8 6}$ & 29767,18 & 43506,55 \\
\hline
\end{tabular}


M. Shofi'ul Amin, dkk, Kinerja Bangunan Bertingkat...

\begin{tabular}{cccccc}
\hline & $1,2 \times 1,075$ & 1 & 860,25 & 57,30 & 387 \\
Pelat Tangga & $2,7 \times 1,75$ & 8 & 25207,34 & 1679,08 & 11340 \\
& Total & & $\mathbf{2 6 0 6 7 , 5 9}$ & $\mathbf{1 7 3 6 , 3 8}$ & $\mathbf{1 1 7 2 7}$ \\
\hline \multirow{3}{*}{ Pelat Bordes } & $1,5 \times 3,15$ & 1 & 2835 & 209,88 & 1417,5 \\
& $1,23 \times 3,15$ & 4 & 9298,8 & 688,42 & 4649,4 \\
& Total & & $\mathbf{1 2 1 3 3 , 8}$ & $\mathbf{8 9 8 , 3 0}$ & $\mathbf{6 0 6 6 , 9}$ \\
\hline
\end{tabular}

Tabel 2. Beban Gravitasi pada Elemen Kolom

\begin{tabular}{|c|c|c|c|c|c|c|}
\hline Lokasi & Jenis & Dimensi (m) & $\begin{array}{c}\text { Berat } \\
\text { Beton } \\
\text { Bertulang } \\
\left(\mathrm{kg} / \mathrm{m}^{3}\right)\end{array}$ & $\begin{array}{l}\text { Berat } \\
(k g)\end{array}$ & $\mathrm{Jml}$ & $\begin{array}{l}\text { Berat total } \\
\quad(\mathrm{kg})\end{array}$ \\
\hline \multirow{5}{*}{$\begin{array}{l}\text { Lantai } \\
\text { Ground }\end{array}$} & K2A 250/700 & $(0,25 \times 0,7) \times 4,2$ & 2400 & 1764 & 2 & 3528 \\
\hline & K2 250/700 & $(0,25 \times 0,7) \times 4,2$ & 2400 & 1764 & 3 & 5292 \\
\hline & $\mathrm{K} 1 \mathrm{~A} 400 / 700$ & $(0,4 \times 0,7) \times 4,2$ & 2400 & 2822,4 & 4 & 11289,6 \\
\hline & K1 400/700 & $(0,4 \times 0,7) \times 4,2$ & 2400 & 2822,4 & 6 & 16934,4 \\
\hline & KL1 200/400 & $(0,2 \times 0,4) \times 4,2$ & 2400 & 806,4 & 4 & 3225,6 \\
\hline \multirow[t]{7}{*}{ Lantai 1-4 } & K1A 300/700 & $(0,3 \times 0,7) \times 3,5$ & 2400 & 1764 & 16 & 28224 \\
\hline & K1 300/700 & $(0,3 \times 0,7) \times 3,5$ & 2400 & 1764 & 24 & 42336 \\
\hline & K2A 250/700 & $(0,25 \times 0,7) \times 3,5$ & 2400 & 1470 & 8 & 11760 \\
\hline & K2 250/700 & $(0,25 \times 0,7) \times 3,5$ & 2400 & 1470 & 12 & 17640 \\
\hline & K0 150/150 & $(0,15 \times 0,15) \times 1$ & 2400 & 54 & 4 & 216 \\
\hline & KL1 200/400 & $(0,2 \times 0,4) \times 3,5$ & 2400 & 672 & 16 & 10752 \\
\hline & & Total Berat Kolom & & & & 151197.6 \\
\hline
\end{tabular}

Tabel 3. Beban gravitasi (vertikal) pada elemen balok

\begin{tabular}{|c|c|c|c|c|c|}
\hline Penampang Balok & Dimensi & $\begin{array}{c}\text { Berat Beton } \\
\text { Bertulang } \\
\left(\mathrm{kg} / \mathrm{m}^{3}\right)\end{array}$ & $\mathrm{Jml}$ & Berat $(k g)$ & $\begin{array}{l}\text { Berat Total } \\
\quad(\mathrm{kg})\end{array}$ \\
\hline \multicolumn{6}{|c|}{ Balok Lt. 1-4 } \\
\hline $250 \times 600$ & $(0,25 \times 0,6 \times 5,435)$ & 2400 & 20 & 1956,6 & 39132 \\
\hline $250 \times 625$ & $(0,25 \times 0,625 \times 6.46)$ & 2400 & 20 & 2422,5 & 48450 \\
\hline $200 \times 600$ & $(0,2 \times 0,6 \times 6.46)$ & 2400 & 16 & 1860,48 & 29767,68 \\
\hline $200 \times 400$ & $(0,2 \times 0,4 \times 1,62)$ & 2400 & 16 & 311,04 & 4976,64 \\
\hline $250 \times 400$ & $(0,25 \times 0,4 \times 1,62)$ & 2400 & 20 & 388,8 & 7776 \\
\hline $250 \times 600$ & $(0,25 \times 0,6 \times 7,6)$ & 2400 & 40 & 2736 & 109440 \\
\hline $250 \times 600$ & $(0,25 \times 0,6 \times 7,45)$ & 2400 & 8 & 2682 & 21456 \\
\hline $200 \times 400$ & $(0,2 \times 0,4 \times 3,8)$ & 2400 & 32 & 729,6 & 23347,2 \\
\hline $250 / 450 \times 600$ & $(0.45 \times 0.6 \times 7.6)$ & 2400 & 8 & 4696,8 & 37574,4 \\
\hline $250 / 450 \times 600$ & $(0.45 \times 0.6 \times 7.45)$ & 2400 & 8 & 4604,1 & 36832,8 \\
\hline \multicolumn{6}{|c|}{ Balok Atap } \\
\hline $200 \times 650$ & $(0,2 \times 0,65 \times 7,6)$ & 2400 & 4 & 2371,2 & 9484 \\
\hline $250 \times 650$ & $(0,25 \times 0,65 \times 6,46)$ & 2400 & 5 & 2519,4 & 12597 \\
\hline $200 \times 650$ & $(0,2 \times 0,65 \times 6,46)$ & 2400 & 4 & 2015,52 & 8062,08 \\
\hline $250 \times 600$ & $(0,25 \times 0,6 \times 7,6)$ & 2400 & 6 & 2736 & 21888 \\
\hline $250 \times 600$ & $(0,25 \times 0,6 \times 7,45)$ & 2400 & 2 & 2682 & 5364 \\
\hline $250 \times 600$ & $(0,25 \times 0,6 \times 5,435)$ & 2400 & 5 & 1956,6 & 9783 \\
\hline $200 \times 400$ & $(0,2 \times 0,4 \times 1,62)$ & 2400 & 4 & 311,04 & 1244,16 \\
\hline $250 \times 650$ & $(0,25 \times 0,65 \times 1,62)$ & 2400 & 5 & 631,8 & 3159 \\
\hline $250 / 450 \times 600$ & $(0.45 \times 0.6 \times 7.6)$ & 2400 & 2 & 4696,8 & 9393,6 \\
\hline $250 / 450 \times 600$ & $(0.45 \times 0.6 \times 7.45)$ & 2400 & 2 & 4604,1 & 9208,2 \\
\hline $150 \times 350$ & $(0,15 \times 0,35 \times 2,3)$ & 2400 & 2 & 289,8 & 579,6 \\
\hline $150 \times 400$ & $(0,15 \times 0,4 \times 1,575)$ & 2400 & 2 & 226,8 & 453,6 \\
\hline
\end{tabular}


M. Shofi'ul Amin, dkk, Kinerja Bangunan Bertingkat...

\begin{tabular}{|c|c|c|c|c|c|}
\hline $150 \times 400$ & $(0,15 \times 0,4 \times 3,15)$ & 2400 & 1 & 453,6 & 453,6 \\
\hline \multicolumn{6}{|c|}{ Balok Tangga } \\
\hline $250 \times 400$ & $(0,25 \times 0,4 \times 3,15)$ & 2400 & 4 & 75 & 3024 \\
\hline $200 \times 300$ & $(0,2 \times 0,3 \times 3,15)$ & 2400 & 5 & 453,6 & 2268 \\
\hline \multicolumn{6}{|c|}{ Balok Lift } \\
\hline $200 \times 400$ & $(0,2 \times 0,4 \times 2,65)$ & 2400 & 10 & 508,8 & 5088 \\
\hline \multicolumn{5}{|c|}{ Total Berat Balok } & 460802,5 \\
\hline
\end{tabular}

Tabel 4. Beban Gravitasi (Vertikal) pada Elemen Dinding Geser

\begin{tabular}{cccc}
\hline Lokasi & Dimensi (m) & Jumlah & Beban Mati $\left(\mathrm{kg} / \mathrm{m}^{2}\right)$ \\
\hline \multirow{3}{*}{ Dinding Geser } & $2,4 \times 4,2$ & 2 & 9676,8 \\
& $3,15 \times 4,2$ & 2 & 12700,8 \\
& $2,4 \times 3,5$ & 8 & 32256 \\
& $3,15 \times 3,5$ & 8 & 42336 \\
\hline & Total & $\mathbf{9 6 9 6 9 , 6}$ \\
\hline
\end{tabular}

Tabel 5. Perhitungan Beban Angin Arah $x$

\begin{tabular}{ccccc}
\hline No & $\begin{array}{c}\text { Koefisien } \\
\text { angin }\end{array}$ & $\begin{array}{c}\text { Lebar dinding } \\
\text { vertikal }(\mathrm{m})\end{array}$ & $\begin{array}{c}\text { Lebar dinding } \\
\text { horizontal }(\mathrm{m})\end{array}$ & $\begin{array}{c}\text { P angina } \\
\mathrm{kg} / \mathrm{m}\end{array}$ \\
\hline \multirow{2}{*}{ P1 } & 0,9 & 4,2 & 3,230 & 488,376 \\
& 0,4 & 4,2 & 3,230 & 217,056 \\
P2 & 0,9 & 4.2 & 5,946 & 899,035 \\
& 0,4 & 4,2 & 5,946 & 399,571 \\
P3 & 0,9 & 4,2 & 4,850 & 733,320 \\
& 0,4 & 4,2 & 4,850 & 325,920 \\
P4 & 0,9 & 3,5 & 3,230 & 406,980 \\
& 0,4 & 3,5 & 3,230 & 180,880 \\
P5 & 0,9 & 3,5 & 5,946 & 749,196 \\
& 0,4 & 3,5 & 5,946 & 332,976 \\
P6 & 0,9 & 3,5 & 4,850 & 611,100 \\
& 0,4 & 3,5 & 4,850 & 271,600 \\
\hline
\end{tabular}

Tabel 6. Perhitungan Tekanan Angin Arah y

\begin{tabular}{ccccc}
\hline No & $\begin{array}{c}\text { Koefisien } \\
\text { angin }\end{array}$ & $\begin{array}{c}\text { Lebar dinding } \\
\text { vertikal }(\mathrm{m})\end{array}$ & $\begin{array}{c}\text { Lebar dinding } \\
\text { horizontal }(\mathrm{m})\end{array}$ & $\begin{array}{c}\text { P angin } \\
\mathrm{kg} / \mathrm{m}\end{array}$ \\
\hline \multirow{2}{*}{ P1 } & 0,9 & 4,2 & 3,8 & 574,560 \\
& 0,4 & 4,2 & 3,8 & 255,360 \\
P2 & 0,9 & 4,2 & 7,6 & 1149,120 \\
& 0,4 & 4,2 & 7,6 & 510,720 \\
P3 & 0,9 & 3,5 & 3,8 & 478,800 \\
& 0,4 & 3,5 & 3,8 & 212,800 \\
P4 & 0,9 & 3,5 & 7,6 & 957,600 \\
& 0,4 & 3,5 & 7,6 & 425,600 \\
\hline
\end{tabular}


M. Shofi'ul Amin, dkk, Kinerja Bangunan Bertingkat...

Tabel 7 Rekapitulasi Kinerja batas Layan Akibat Simpangan Arah X dan Y

\begin{tabular}{cccccccc}
\hline \multirow{2}{*}{ Lantai } & Hsx & \multicolumn{2}{c}{ Beban Gempa } & \multicolumn{2}{c}{ Beban Angin } & \multirow{2}{*}{$\Delta_{a}$ (ijin) } & \multirow{2}{*}{ Keterangan } \\
\cline { 2 - 5 } & & $\Delta \mathrm{x}$ & $\Delta \mathrm{y}$ & $\Delta \mathrm{x}$ & $\Delta \mathrm{y}$ & & \\
\cline { 2 - 5 } & $(\mathrm{mm})$ & $(\mathrm{mm})$ & $(\mathrm{mm})$ & $(\mathrm{mm})$ & $(\mathrm{mm})$ & $(\mathrm{mm})$ & \\
\hline Atap & 3500 & 8,577 & 8,341 & 2,952 & 5,688 & 87,5 & Aman \\
5 & 3500 & 10,754 & 11,999 & 3,572 & 6,265 & 87,5 & Aman \\
4 & 3500 & 10,595 & 14,372 & 4,335 & 6,831 & 87,5 & Aman \\
3 & 3500 & 10,892 & 15,756 & 4,514 & 6,368 & 87,5 & Aman \\
2 & 4200 & 9,431 & 13,754 & 3,757 & 4,663 & 105 & Aman \\
1 & 0 & 0.0000 & 0.0000 & 0.0000 & 0.0000 & 0 & Aman \\
\hline
\end{tabular}

